\title{
THE GOOD GOVERNANCE IMPLEMENTATION AT VILLAGE IN EAST NUSA TENGGARA PROVINCE
}

\author{
Ella Wargadinata ${ }^{1}$, dan Ika Sartika ${ }^{2}$ \\ ${ }^{1}$ IPDN, Jl. Ir. Soekarno, Jatinangor, ${ }^{3}$ IPDN, Jl. Ir. Soekarno KM 20, Jatinangor, \\ ${ }^{2}$ IPDN, Jl. Ampera Raya Cilandak Timur, Jakarta Selatan, Indonesia, \\ E-mail: ella@upm.ipdn.ac.id
}

\begin{abstract}
The Government of Indonesia has implemented a progressive policy on rural development since 2015 through distributing enormous budget that has never been given so far, called as village fund policy. This policy is intended to empowering of poor people in the village throughtout the development of village infrastructure to eliminate poverty or for poverty alleviation. In the period of 2015-2018, the budget increased significantly, reach one billion IDR for each village accros the country. From the national spending recorded that in 2015, the village fund reaches IDR 20.7 trillion, increased to 47 trillion in 2016, 60 trillion in 2017 and 60 trillion in 2018. The research tries to reveal the implementation of Village Fund Policy in East Nusa Tenggara Province, as the third poorest in Indonesia. Research conducted in five villages in Ende and East Timor Tengah Regency, based on random purposive sampling method, involved 204 respondents. Reseach used quantitative approach through Discriminant analysis and good governance concept used as a basic framework. The result from data analysis showed that people participation and village official's responsiveness came as the succes factor for village fund policy management in East Nusa Tenggara Province. This research implies that the Village Fund policy will only succeed if good collaboration is created between the community as the subject of development and the village government as the manager of development policies at the lower levels.
\end{abstract}

Key words: village fund: poverty alleviation; participation; responsiveness

\section{IMPLEMENTASI TATA KELOLA PEMERINTAHAN DESA YANG BAIK DI PROVINSI NUSA TENGGARA TIMUR}

\begin{abstract}
ABSTRAK. Pemerintah Indonesia melakukan kebijakan pembangunan perdesaan yang sangat progresif sejak tahun 2015 dengan mengucurkan dana besar yang belum pernah dilaksanakan sebelumnya, disebut dengan dana desa. Kebijakan ini digunakan untuk memberdayakan masyarakat perdesaan dengan tujuan akhir untuk mengentaskan kemiskinan. Periode 2015-2018, anggaran dana desa terus naik secara signifikan, hampir satu milyar/desa. Catatan APBN menunjukan pada tahun 2017 mencapai 20,7 Triliun, pada tahun 2017 naik menjadi 47 triliun dan mencapai 60 triliun pada tahun 2018. Penelitian ini berusaha mendapatkan gambaran tentang pelaksanaan kebijakan dana desa di Provinsi NTT yang tercatat sebagai provinsi termiskin ketiga di Indonesia. Penelitian dilakukan di lima Desa dari Kabupaten Ende dan Kabupaten Timor Tengah Utara berdasarkan teknik sampel acak bertujuan, melibatkan 204 responden. Penelitian dilakukan dengan menggunakan pendekatan kuantitatif melalui analisis diskriminan untuk melihat faktor penentu pelaksanaan kebijakan Dana Desa di Provinsi NTT, dengan menggunakan konsep good governance sebagai pisau analisis. Hasil analisis data memperlihatkan bahwa variabel partisipasi masyarakat dan daya tanggap pemerintah desa muncul sebagai faktor kunci keberhasilan kebijakan dana desa di perdesaan Provinsi NTT. Penelitian ini berhasil menyiratkan bahwa kebijakan Dana Desa hanya akan berhasil apabila tercipta kolaborasi yang baik antara masyarakat sebagai subjek pembangunan dan pemerintah desa sebagai pengelola kebijakan pembangunan di tingkat bawah.
\end{abstract}

Kata kunci: Dana desa; Pengentasan kemiskinan; Partsipasi; Daya tanggap

\section{INTRODUCTION}

Despite the fact of increasing macro economic indicators in Indonesia, however, the gap between cities and rurals are still wide. In the year 2014, The Government of Indonesia released Village law which put Village as a development machine to reach the poor at the rural level. Along with this law, The GOI has a development shifting policy paradigm called "Building from the periphery". The GOI put village and underdeveloped areas as a top priority on the development agenda. The rural-based development in Indonesia will directly accelerate poverty alleviation, reducea regional gap and strengthen the country's economy. Village fund policy is one of the progressive rural development agenda under a new development paradigm. This policy is intended to empowering of poor people in the village throughtout the development of village infrastructure to eliminate poverty or for poverty alleviation. In the period of 2015-2018, the budget increased significantly, reach one billion IDR for each village accros the country. From the national spending recorded that in 2015, the village fund reaches IDR 20.7 trillion, increased to 47 trillion in 2016, 60 trillion in 2017 and 60 trillion in 2018. Each village will receive national fund one billion Indonesia currency as long as the village government fullfill the national's report standard. Beside village fund policy which budget transfer directly from national revenue, The village also receives 
local fund from municipality budget called as Village Fund Allocation. The differences beteen both schemes are on the utilization, if national transfer used for infrastructure and rural economic empowerment, the municipal budget will go for village official cost. However, both are intended to boost rural economy development.

Some research revealed interesting findings on village fund implementation, the program suceed to strengthen social cohession among rural people (Faisal $\&$ Nain, 2018). The village fund policy found has a strong relation with rural people participation (Daraba, 2017); (Mustanir \& Darmiah, 2016). Some paper shows the contradictive result as found in Bogor. It exposed that village fund policy was prone to corrupt since the participation and control were low and lack of capacity from village officials to manage the budget was the crucial factors of this program (Subandi, 2017). Research in a poor remote village in Majene Regency, West Sulawesi presented another fact of rural development in Indonesia. The village fund program was not adequate to enhance rural people welfare. Lack of infrastructure, lack of clean water were found in this village (Akbar \& Prabawati, 2018). Due to the nature of the policy and the diversity of villages in Indonesia, the village fund policy is salient subject to explore.

Good Governance is a concept which guarantees the implementation of responsible development management in line with democratic principles. The implementation of good governance principles will prevent bias of government activity and prevent political and administrative abuse. Research from Bangladesh was convincingly proved that practices good governance concept will reduce corruption (Saha, 2014). The principle of good governance gives a paradigm shift in government and public relation. By now, the government act as a public servant. Good governance is considered as a new management paradigm or administration development. This role assigns the government as an agent of change from society development, particularly in developing countries. The government is also called as an agent of development because the shift is desired (Rustiarini, 2016). Others opinion said that poverty can decrease through good governance implemention (King, 2015).

Good governance was initially applied to companies throughout the world with the aim to formulate concepts that must be applied by creating inherent supervision of the company and its internal management. Therefore, the Good Corporate Governance was formed with the main principles: transparency, accountability, equity, responsibility and responsiveness (Wijoyo, Salman, \& Abrianto, 2018). Corporate Governance concept was proposed in order to achieve a more transparent corporate management for all utilization of financial statements. If this concept is implemented well, the transparent corporate management will be getting better and It is expected that economic growth will continue to increase and will benefit many parties (Astuti \& Yulianto, 2016). Basically, good corporate governance is implemented to achieve company goals by looking at organizational experiences in the past (OBE, 2017).

The village governments as an instrument of state power which is at the forefront of serving the interests of the community while realizing national ideals must be able to translate the principles of good governance of the government (Dungga, Tome, \& Moha, 2014). The village government requires to take notice of the implementation of good governance (Rosielita, Sulindawati, \& Sinarwati, 2017). Nowadays, good governance is not only dominated by the government. Societies start showing the capacity in terms of development. Societies and governments components should work together to create good governance, particularly in terms of village funds management (Rustiarini, 2016). The concept of good governance is used as an institutional framework to strengthen village autonomy. The implementation of good governance principles then is more popular as good village governance (Antlöv, Wetterberg, Dharmawan, \& Antlöv, 2016).

Many research about good governance have been carried out from local government level (Lastiar Hutapea \& Widyaningsih, 2017), (Napitupulu, Hakim, \& Noor, 2016), (Utoyo, 2017), (Sasundame, Tulusan, \& Kalangi, 2016) and (Parapat \& Yuliani, 2017) to village level (Maria Fransisca Vina Febriani Manaan, 2017), (Astuti \& Yulianto, 2016), (Rustiarini, 2016), (Futra, 2016), (Richardo Juniaster Tampubolon, 2014), and (Dungga et al., 2014), event NGO level (Kanagaretnam, Lobo, \& Whalen, 2007). We examine the relationship between the quality of corporate governance and information asymmetry in the equity market around quarterly earnings announcements. We use the change in market liquidity (i.e., bid-ask spreads and depths. Considering that villages in Indonesia have distinctive features and based on previous research, it can be concluded that the implementation of good governance principles in village level is still open to be developed. The law which has passed the 7-year discussion process regulates the source of funding for 73 thousand villages originating from central government donations and regional cash injections. Based on the law, each village receives a substantial amount of funds and can even reach one billion rupiahs per village. The Village Law provides a more certain guarantee that each village receives funding from the government through the state and regional budgets which are multiplied, far above the amount that has been available in the village budget (Rustiarini, 2016). Based on these reasons, this paper 
specifically would analyze the implementation of good governance principle in managing village funds.

Villages development in East Nusa Tenggara (NTT) Province has differences compared to other villages. NTT Province pioneers holistic, integrative village-based development policies including supports climate change adaptation as well. The budget for village funds will be greatly meaningful for the development of NTT Province, it can be seen from the value of the HDI of NTT Province still at a moderate level with a value of 63.13 far below the national average which has reached 70.18

Meanwhile, the number of poor people in NTT is the third largest in Indonesia, after the provinces of Papua and West Papua (Badan Pusat Statistik Provinsi Nusa Tenggara Timur, 2018). In addition, the position of NTT in the border region with developing countries of Timor Leste and developed countries in the Australia Continent has good potential in terms of natural resources (Matondang, 2017). Village funds are expected to alleviate poverty in NTT Province through the use of natural resources. Based on the above description mentioned, this study would try to see the implementation of some principles of good governance in managing village funds and analyze the determinants of the success of managing village funds in NTT Province.

The good governance principles which would be used as analysis materials in this study are four of the nine principles that have been published by UNDP. The nine principles which have been implemented in APBD forming in Padang Sidempuan City: (1) Participation; (2) Rule of Law, (3) Transparency, (4) Responsiveness, (5) Efficiency and Effectiveness, (6) Accountability, (7) Strategic Vision, (8) Consensus Orientation, and (9) Equity (Parapat \& Yuliani, 2017). Other studies did not use nine principles as indicators, but according to the needs and problems to be addressed. Other researchers used six indicators (Rosielita et al., 2017), five indicators (Napitupulu et al., 2016), four indicators (Utoyo, 2017) and (Richardo Juniaster Tampubolon, 2014), three indicators (Ultafiah, 2017) and (Hamsinar, 2017), two indicators (Maria Fransisca Vina Febriani Manaan, 2017) and (Widyanti, 2017), and even one indicator (Irma, 2015). From previous research, it can be seen that indicators that are often used to analyze governance are: participation, transparency, accountability, and responsiveness. Therefore, the research on village fund management in the NTT Province will use these four indicators.

\section{METHOD}

Research conducted during March-August 2017. Reseach location selected through purposived sampling. Two municipalities are selected: Ende and East Timor Tengah. The research located in three districts in Ende:
Maurole, Detusoko, and Wewaria. Two Districts in East Timor Tengah: Biboki, and South Boboki. The total number of sample is 204 respondents. The sampling technique used is random sampling. Following are the number of respondents in each village. This research was conducted with a quantitative approach which consists of two analyzes, namely: descriptive statistics to see the respondent's response to the four aspects of good governance, and discriminant analysis to determine the determinants of the successful of village fund management. Primary data was obtained from the results of a survey of stakeholders in the village fund management consisted of village communities, sub-district, district officials who deal directly with village funds. There are 204 samples and using discriminant analysis. The research questionnaire as the main instrument in this study was compiled based on four determining variables for the successful of village fund management, namely: Participation (X1); Accountability (X2); Transparency (X3); Responsiveness (X4); and the Successful of Village Fund Management (Y) .

The steps in the research analysis based on Rahman, Wiediartini, \& Sari (2018) framework: (1) Conducting survey data collection on the success of village fund management viewed from four dimensions; (2)Conducting descriptive analysis;(3) Testing the assumption of normal multivariate distribution on predictor variable data; (4) Testing the assumption of homogeneity. (5) Performing discriminant analysis to get linear functions. The variables used in this study are one response variable (Y) and six predictor variables $(\mathrm{X})$.

\section{RESULT AND DISCUSSION}

\section{Descriptive Analysis of Participation}

In public administration, the meaning of public participation is the willingness of public officials to participate in community citizens both individually and in groups (NGOs/Interests Group) in various public administration/government activities and actions. In a centralized government, public participation is greatly overlooked because the overall actions and policies of the government are determined by the authorities in the central government. However, in a decentralized government system, public participation is important because the goal of decentralization is basically the participation of local government and citizens in various stages of government work. The participation of citizens is getting important because they are being an integral part of development activities, this is also a feature of democratic government (Silalahi \& Syafri, 2015).

Based on Table 3 above, it can be analyzed that the actual society participation in managing village funds is still not optimal. The societies are usually mobilized and 
directed by the apparatus to get involved in working on projects whose funds come from village funds. Society participation in overseeing the village funds utilization is good, but in its formulation, not all communities are involved in planning the fund's allocation. The village community participation in planning development activities, planning the development finance activities, also providing advice and opinions are still relatively weak. This happens because the level of education is still low and the culture of asking or giving input directly is still difficult because it is not common. The relatively good participation is in terms of physical willingness. Most people are not difficult to be asked to attend various activities carried out by the village government. They are even willing to provide makeshift material in order to make the activities run smoothly. This is due to the nature of mutual cooperation that is still inherent in some parts of Indonesian society. Not only the materials, but they are also even ready to provide moral support for the activities. This is a very valuable social aspect and must be maintained for all time. Rural communities in NTT Province generally have high participation in utilizing development results and maintaining development outcomes, even improving if there is damage. This can not be separated from the habits of rural communities who highly uphold peace and comfort so that the results of development that have been given by the government will be maintained as well as possible. There are some development results which are maintained properly, especially the results of physical development, such as roads, bridges, dams, toilets, and other physical buildings. The phenomena of participation from local people for their development was inline with (Widiyanti, 2017) result which showed that participation through rural local wisdom context will enhance rural people in village fund actively.

Table 1. Descriptive Analysis of Participation

\begin{tabular}{lcccc}
\hline \multirow{2}{*}{\multicolumn{1}{c}{ Indicator }} & \multicolumn{4}{c}{ Response } \\
\cline { 2 - 5 } & Yes & $\%$ & No & $\%$ \\
\hline Participate on devt. planning & 22 & 11 & 182 & 89 \\
Participate in budget planning & 29 & 14 & 175 & 86 \\
Give adive and suggestion & 39 & 19 & 165 & 81 \\
Physicall participation & 39 & 19 & 165 & 81 \\
Financial participation & 55 & 27 & 149 & 73 \\
Thought Participation & 83 & 41 & 121 & 59 \\
Utiilize development result & 159 & 78 & 45 & 22 \\
Preserve development result & 149 & 73 & 55 & 26 \\
Maintain development result & 166 & 81 & 38 & 19 \\
\hline
\end{tabular}

Research 2017

\section{Descriptive Analysis of Accountability}

Accountability is essentially the delivery of reports from government officials to related parties regarding activities carried out in a certain period of time (Silalahi \& Syafri, 2015). Accountability can be interpreted as an obligation of public administrator/government officials to account for and explain to the principals what they have done, decisions and actions taken regarding the implementation of the main tasks and functions that they hold for the public interest. In public administration, public administrators require the bureaucracy to act in "public interest". In this study, accountability would be measured through routine budget use report activities as well as accountability for the rights that have been given in the form of reports to supra organizations and organizations in the village. Accountability came up as one of the important indicators in good governance context (Khotami, 2017).

As general, rural accountability will be delivered through institutional management, social organizations and local cultures (Nurlinah, Haryanto, \& Musdah, 2018). And in terms of village fund, accountability can be seen from making a report on the use of a budget that is made routinely as well as accountability for the rights given in the form of reports to supra organizations and village organizations. When it comes to administrative, reporting and responsibility have been carried out routinely, even though there are still some villages that have some difficulties due to limited human resources in the villages. However, this can be solved with assistance from the Community and Village Empowerment (PMD) Service in the district. The discipline of reporting and responsibility is also caused by many parties who oversee the management of village funds. Thus, the village apparatus cannot play games, especially with the case of two villages in North Timor Tengah District which were criminalized because it was alleged that there were frauds in the use of village funds which were used to build the physical condition of the village. Lack of accountability on the village fund will be lead to corruption among the village head and officials (Ash-shidiqqi \& Wibisono, 2018).

Table 2. Descriptive Analysis of Accountability

\begin{tabular}{lcccc}
\hline \multirow{2}{*}{ Indicator } & \multicolumn{4}{c}{ Response } \\
\cline { 2 - 5 } & Yes & $\%$ & No & $\%$ \\
\hline Report for community & 188 & 92 & 16 & 8 \\
Report for Local Govt & 172 & 84 & 32 & 16 \\
\hline & \multicolumn{4}{c}{ Research 2017 }
\end{tabular}

Basically, village officials always try to report on the use and responsibility of village fund management according to a predetermined schedule. The district government through the PMD Service always attempts to assist village officials so that they can prepare reports and accountability for the use of the budget that comes from village funds properly and on time. The problem faced is the quality of reporting that is still not good and does not meet the standards. Online application-based reporting is also a problem in the village, related to limited 
human resources in the village and network difficulties, particularly when the distance is far from cities. Reporting and responsibility of village fund management are always routinely and regularly delivered to PMD Service. All villages have poured everything into the legal basis for managing village funds in the form of village regulations.

It is also revealed that village officials always attempt to fulfill the obligation to report and account for the village funds management to the central government through the district government. Village officials have tried to be proactive to the district government through the PMD Service to look for various regulations that must be adhered to in managing village funds. Changes to regulations that often suddenly make village devices confused to follow the rules. The weakness is the quality of human resources to prepare accountability reports that must be in accordance with the rules and application-based. There is fear among the village officials regarding the procurement of goods and services that has to be in accordance with the rules, because there are several villages affected by the case, and the village head is dealing with the law. The obedience of village's officials to make progress and finance report also recorded in several areas, in Sragen (Prasetyo, Suharno, \& Widarno, 2016) and in Sambas (Yuliansyah \& Munandar, 2017),

\section{Descriptive Analysis of Transparency}

Transparency is considered as access to information. It allows citizens to gather information about government policies and behavior (Alom, 2018). It is also considered to increase public trust in the government (Nunkoo, Ribeiro, Sunnassee, \& Gursoy, 2018). Whereas transparency in finance can be divided into transparency at the budgeting stage, implementation phase, and the examination and reporting stages (Salle, 2016). Transparency has become an inseparable part of the implementation of modern democratic regional government nowadays, especially in the provision of public services, including in the management of village funds. In this study, transparency was made more operational by observing information access on the amount of budget received, the use of budget, reporting, complaints, and to get an explanation.

Transparency is a village government responsibility for reporting and presenting the village fund activities that have been planned to the local people. Transparency on village fund management basically applied in a similar way in every village. Mostly it is displayed on a big screen/ billborad which everyone will notice on it. The board contains detailed data on how much money received in the current year, program planning and budget. Billborad put in the village office. This transparency mechanism aimed to gain direct control from the villagers. Reseachs show that transparency through billborad was common and already implemented well (Desico \& Purnomo, 2018). The interview results with all the informants and from the observation results made, it was found that the established cooperative relationships are good, all of them have worked together to support each other. It is just that sometimes problems occur because usually not all activities can be informed to the community so that news seems negative to society. In supporting the realization of good governance, society is one of the tools to encourage the implementation of good governance principles. Everything related to society must be made openly. Moreover, the average village communities have a low level of education, so that in matters of village funds, of course, it must be opened and explained openly so that the communities can support the running of the village government instead of thinking badly about the funds that have been entered.

Table 3. Descriptive Analysis of Transparency

\begin{tabular}{lcccc}
\hline \multirow{2}{*}{\multicolumn{1}{c}{ Indicator }} & \multicolumn{4}{c}{ Response } \\
\cline { 2 - 5 } & Yes & $\%$ & No & $\%$ \\
\hline Budget received & 110 & 54 & 94 & 46 \\
Budget utilization & 110 & 54 & 94 & 46 \\
Acess on information & 149 & 73 & 55 & 27 \\
Acess for complaints & 126 & 62 & 78 & 38 \\
Question and Answer pool & 138 & 68 & 66 & 32 \\
\hline
\end{tabular}

Research 2017

Budget Government efforts to make the village funds management have been maximized. Access to information is relatively easier, especially for villages that already have an internet network, publications about the use of village funds have been transparent. For villages in the remote districts in NTT Province, transparency has been seen as well. The village government displays information needed by the community in the village office and is open to all village communities. Even village officials are very open to providing answers to village community questions regarding village funds. Information that can be accessed by the community includes the amount of the budget received, the use of budget, reporting, and complaints.

Almost all villages publish their budget in the village office so that people could access them easily. Head of Sub-district with the district government and sub-district forums always try to provide important information to village officials and the community. Village officials always display the Regional Budget in the village office with the expectation that the community and other parties can easily access it. The village apparatus also always facilitate people who want to know everything about village funds. Online publications continue to be sought by the village government with the help of assistants and staff at the district PMD Service. The communities also feel that access to information is easier, but they want 
something more important than just the budget publication. The communities can find out about the Regional Budget easily, which shows the source and use of the budget in the village, one of which comes from village funds.

\section{Descriptive Analysis of Responsiveness}

Responsiveness literally means quick to respond or react appropriately or sympathetically in answering. In the field of public administration, the public response shows how fast and accurate an administrator can recognize and track the fluctuations in the citizen's needs, and provide everything needed by citizens (Liao, 2018). The increase of public responsiveness towards the needs and preferences of local residents is also a goal of decentralization in democratic countries. Public responsiveness in the local context refers to the ability of local bureaucrats to respond quickly and precisely to the needs and demands of community members. The meaning of responsiveness in question on this matter is the responsiveness of public services (public service responsiveness). In this study, the responsiveness that would be seen is the responsiveness of the village apparatus in managing village funds towards stakeholder input and complaints and responsiveness to the wishes and aspirations of the community.

Responsiveness is an absolute requirement for the initial steps of implementing good governance. It is useless to promise to implement good governance if criticism or suggestions for progress in various matters of law enforcement, performance, accountability, and equal rights and obligations of a person/society, always slow or not responded to by the government. A responsive government to community problems is a dream of good governance. The role of the government must understand the objective needs of its people, do not wait for them to convey those desires, the government is expected to be proactive in studying and analyzing their needs, to then produce strategic policies to meet the public interests that are pro-society, without discrimination against groups. Excellent service is one form of business or activity that is expected to be able to improve the performance of an agency or institution for a better condition than before. Excellent service is the best service that can be called very good or the best due to the accordance with the service standards that are in effect or owned by service providers. The essence of public service is the provision of excellent service to the communities which is the embodiment of the obligations of government officials including village officials as community servants. In line with this, excellent service is also expected to motivate other service providers to carry out their duties diligently and competently. (Sutiyo \& Maharjan, 2017) shows that responsiveness in Indonesia rural areas already existed and held by the village head. Regarding village fund management, the indicator of responsiveness addressed to the village head and it's officials to respond at the need or suggestion of the village community.

Table 4. Descriptive Analysis of Responsiveness

\begin{tabular}{lcccc}
\hline \multirow{2}{*}{ Indicator } & \multicolumn{4}{c}{ Response } \\
\cline { 2 - 5 } & Yes & $\%$ & No & $\%$ \\
\hline $\begin{array}{l}\text { Quick actions on people } \\
\text { complaints }\end{array}$ & 56 & 27 & 148 & 73 \\
Open mind for suggestion & 44 & 22 & 160 & 78 \\
\hline
\end{tabular}

Research 2017

Table 6 above showed that responsiveness to input and complaints from stakeholders, as well as responsiveness to the wishes and aspirations of the community, is still not optimal. This is understandable because the quality and quantity of human resources in the village are also limited. It is not easy to follow the wishes of the central government delivered through the district government through the PMD Service, particularly regarding reporting requirements that must be online. Many obstacles faced by village officials related to this necessity. Not only competencies must be improved, but also internet networks that involve other parties need to be addressed.

People's complaints or aspirations are sometimes difficult to execute immediately concerning community needs are varied, but the budget was limited. In addition, the increasing needs of rural communities also cause difficulties in determining priorities in the use of village funds. The village apparatus has tried to respond to all input and complaints from stakeholders, but it is still not optimal because there are many interested parties with different desires. The desires and aspirations of the people also still have not been well netted because the village apparatus is busy with various administrative matters.

Village officials still need to be fostered so that they can improve their performance in managing village funds. The PMD Service always tries to help village officials to be able to respond to the parties involved in managing village funds including the community. Interventions from parties that are increasing make it difficult for village officials to respond to their input and desires.

The efforts of village officials to respond to input and complaints from stakeholders still need to be improved, especially those relating to the procurement of goods and services and financial report examiners, in this case, the Audit Board of the Republic of Indonesia (BPK). Efforts to capture people's aspirations are also not optimal, because village officials are too preoccupied with administrative matters, while community initiatives cannot be expected.

Village officials find it difficult to follow the government's willingness to manage village funds, 
moreover, regulations often change. Application-based financial reports still make it difficult for village officials, so the examiners are often not satisfied. Suppliers are also one of the parties who are sometimes troublesome with various requirements and price changes, sometimes quality is also low.

The communities feel that the village apparatus must be more proactive in capturing the aspirations of the village communities. Village officials must continue to improve their performance in meeting stakeholders' wishes.

\section{Determinant Factors}

Descriptive analysis of the four dimensions of good governance above has not been able to show which dimension most strongly determines the success of managing village funds in NTT Province. Therefore, the next analysis uses discriminant analysis. Discriminant analysis is one of the statistical techniques that can be used in the relationship of dependencies (relationships between variables where it can be distinguished which response/ dependent variables and which explanatory/independent variables). More specifically, discriminant analysis is used in cases where the response variable $(\mathrm{Y})$ is in the form of qualitative data and explanatory variables $(\mathrm{X})$ in the form of quantitative data. The discriminant analysis aims to classify an individual or observation into mutually exclusive and exhaustive groups based on a number of explanatory variables.

The first step in discriminant analysis is the normality test of the data using graphs and the Pearson correlation test between the Mahalanobis distance and the chi square value. The mahalanobis result shows that the data are normally multivariate distribution because these scatterplots tend to form a straight line and more than $50 \%$ the value of the Mahalanobis distance is less or equal to the q value. In addition to paying attention to the scatterplot, it can be done through the Pearson correlation test. Correlation result is 0.987 which shows a very high correlation coefficient. Sig value $(0,000)<0.05$ means that there is a significant correlation. In this scatterplot, the data comes from samples that are normally multivariate distributed. The second step is the multicollinearity test, with the results show that there are no numbers that reach 0.5 or above. It concluded that there is no multicollinearity in the data.The third step is to test the equality of the variance-covariance matrix (homoskedasticity). Statistical data revealed the null hypothesis accepted because the $\mathrm{p}$ value (Sig.) is more than 0.05 (in 95\% confidence level). Meaning, research data comes from populations that have similar variance-covariance matrix (homoskedasticity). Moreover, the analysis process can proceed. Table 5 describes the results of discriminant analysis through an average vector similarity test.
Table 5. Tests of Equality of Group Means

\begin{tabular}{llllll}
\hline & $\begin{array}{c}\text { Wilk's } \\
\text { Lambda }\end{array}$ & \multicolumn{1}{c}{$\mathrm{F}$} & df1 & df2 & Sig. \\
\hline Participation $\left(\mathrm{X}_{1}\right)$ & 825 & 42.842 & 1 & 202 & .000 \\
Accountability $\left(\mathrm{X}_{2}\right)$ & .999 & .140 & 1 & 202 & .709 \\
Transparency $\left(\mathrm{X}_{3}\right)$ & .996 & .835 & 1 & 202 & 362 \\
Responsiveness & .853 & 34.872 & 1 & 202 & .000 \\
$\left(\mathrm{X}_{4}\right)$ & & & & & \\
\hline
\end{tabular}

Research, 2017

The results of data processing concluded that the variables $\mathrm{X}_{1}$ and $\mathrm{X}_{4}$ have different averages for both groups, namely the management of village funds is good and not good. This shows that there are differences between respondents who assess good and bad for the management of village funds related to Participation $\left(\mathrm{X}_{1}\right)$ and Responsiveness $\left(\mathrm{X}_{4}\right)$. While variables $\mathrm{X}_{2}$ and $\mathrm{X}_{3}$ have an average that is not different/the same for the two groups, namely the management of village funds is good and not good. This shows that there is no difference between respondents who rate good and bad management of village funds related to Accountability $\left(\mathrm{X}_{2}\right)$ and Transparency $\left(\mathrm{X}_{3}\right)$. Thus, there are two variables that differ significantly for the two discriminant groups namely Participation $\left(\mathrm{X}_{1}\right)$ and Responsiveness $\left(\mathrm{X}_{4}\right)$. The results of the discriminant analysis are in accordance with the results of research on the application of the principles of good governance in urban planning (Utoyo, 2017). That is, indicators of participation and responsiveness are the two main indicators as key success factors in the administration of government in Indonesia. Meanwhile, based on the results of the formation of linear functions as shown in the table below, the shape of the linear function as is: $\mathrm{Y}=-9,569+0,068 \mathrm{X}_{1}+0,058 \mathrm{X}_{4}$.

Table 6. Canonical Discriminant Function Coefficients

\begin{tabular}{lrr}
\hline & \multicolumn{2}{c}{ Function } \\
\cline { 2 - 3 } & \multicolumn{1}{c}{1} \\
\hline Participation (X1) & & .068 \\
Responsivenss (X2) & .058 \\
(Constant) & -9.569 \\
\hline Research 2017 & \\
\hline
\end{tabular}

\section{CONCLUSION}

Basically, the four principles of good governance have been applied in managing village funds in the NTT Province. Most of the village communities already knew of the existence of this village fund, but in participation, there still needed to be hard work from village officials to invite the community to play an active role in managing village funds. Initiatives from the community are still low. From the aspect of accountability, it has been relatively 
good, assessing from the reporting and accountability of the use of the budget sourced from village funds. Access to information is getting easier. All parties have tried to make the management of village funds more transparent. The response to stakeholder input and desires is still not well implemented. This is due to the large number of stakeholders that must be fulfilled by village officials. The determining factor for the success of village funds is participation and responsiveness. It means that the management of village funds will succeed if active participation from the community has taken place in all villages, and the responsiveness of the authorities to the demands of the government and the aspirations of the people is quite high.

\section{ACKNOKLEDGMENT}

Cordially, we sincere to the IPDN Rector and the Head of the Research and Strategic Study which provide financial, technical and moral support for lecturer to do research.

\section{REFERENCES}

Akbar, M. \& Prabawati, I. (2018). Implementasi Kebijakan Dana Desa di Desa Seppong Kecamatan Tammerodo Sendana Kabupaten Majene. Publika, 6, (8), 1-9.

Alom, M. M. (2018). Proactive transparency and outward accountability of frontline public bureaucracies: An integrated model. International Journal of Productivity and Performance Management, 67, (4), 611-628. https://doi.org/10.1108/ IJPPM-08-2016-0169

Antlöv, H., Wetterberg, A., Dharmawan, L., \& Antlöv, H. (2016). Village Governance, Community Life, and the 2014 Village Law in Indonesia. Bulletin of Indonesian Economic Studies, 49, (18 March), 1-42. https://doi.org/10.1080/00074918.2015.112 9047

Ash-shidiqqi, E. A., \& Wibisono, H. (2018). Corruption and Village: Accountability of Village Fund Management on Preventing Corruption ( Problems and Challenges ). Journal of Indonesian Legal Studies, 3, (02), 195-212.

Astuti, T. P., \& Yulianto. (2016). Good Governance Pengelolaan Keuangan Desa Menyongsong Berlakunya Undang-Undang Nomor .6 Tahun 2014. Berkala Akuntansi Dan Keuangan Indonesia, 1, (6), 1-14.
Badan Pusat Statistik Provinsi Nusa Tenggara Timur. (2018). Provinsi Nusa Tenggara Timur Dalam Angka 2017. (Bidang Neraca Wilayah dan Analisis Statistik, Ed.). Jakarrta: CV. Nario Sari, Jakarta.

Daraba, H. D. (2017). Pengaruh Program Dana Desa Terhadap Tingkat Partisipasi Masyarakat di Kecamatan Galesong Utara Kabupaten Takalar. Sosiohumaniora, 19, (1), 52-58.

Desico, Z., \& Purnomo, E. P. (2018). Transparansi dalam pengelolaan dana desa. ResearchGate, (December), 1-19.

Dungga, W. A., Tome, A. H., \& Moha, A. (2014). Penerapan Prinsip Good Governance dalam Tata Kelola Pemerintahan Desa di Kecamatan Telaga Jaya Kabpaten Gorontalo. Maksigama Jurnal Hukum, 11, (1), 1-10.

Faisal, M., \& Nain, U. (2018). Implikasi Pelaksanaan Program Dana Desa Terhadap Kohesi Sosial di Desa Tamalate Kabupaten Takalar. Sosiohumaniora, 20, (3), 222-230. https://doi. org/10.24198/sosiohumaniora.v20i3.16070

Futra, H. (2016). Implementasi Good Governance dalam Bidang Administrasi Desa, Studi Kasus Dana Desa di Desa Jubung Kecamatan Sukorambi Kabupaten Jember. Universitas Muhammadiyah Jember.

Hamsinar. (2017). Pengaruh Partisipasi Masyarakat, Akuntabilitas, dan Transparansi Kebijakan Publik Terhadap Kualitas Laporan Keuangan Pemerintah Daerah Dengan Sistem Pengendalian Intern Sebagai Variabel Moderat. Universitas Islam Negeri Alauddin Makassar. Retrieved from http://ejournal.upi.edu/index.php/aset/article/ view/5446

Irma, A. (2015). Akuntabilitas Pengelolaan Alokasi Dana Desa (Add) Di Kecamatan Dolo Selatan Kabupaten Sigi. E-Jurnal Katalogis, 3, (1), 121137. Retrieved from http://jurnal.untad.ac.id/ jurnal/index.php/katalogis/article/view/4254

Kanagaretnam, K., Lobo, G.J., \& Whalen, D.J. (2007). Does good corporate governance reduce information asymmetry around quarterly earnings announcements? Journal of Accounting and Public Policy, 26, (4), 497-522. https://doi.org/10.1016/j. jaccpubpol.2007.05.003

Khotami. (2017). The Concept of Accountability in Good Governance. In Advances in Social Science, Education and Humanities Research (ASSEHR) 163, pp. 30-33. ATLANTIS PRESS. 
King, S. (2015). Political capabilities for democratisation in Uganda : good governance or popular organisation building ? Third World Quarterly, 36, (4), 744-760. https://doi.org/10.1080/01436597.2015.1024436

Lastiar H. \& Widyaningsih, A. (2017). Pengaruh Good Government Governance Dan Ukuran Legislatif Terhadap Kinerja Pemerintah Daerah (Studi Pada Pemerintah Provinsi Di Indonesia). Jurnal ASET (Akuntansi Riset), 9, (1), 173. https://doi. org/10.17509/jaset.v9i1.5446

Liao, Y. (2018). Toward a Pragmatic Model of Public Responsiveness: Implications for Enhancing Public Administrators' Responsiveness to Citizen Demands. International Journal of Public Administration, 41, (2), 159-169. https://doi.org/1 $0.1080 / 01900692.2016 .1256305$

Maria Fransisca Vina Febriani Manaan. (2017). Penerapan Prinsip Good Government Governance Dalam Perencanaan, Pelaksanaan, dan Pertanggung jawaban Alokasi Dana Desa; Studi Kasus Desa Wijirejo Kecamatan Pandak Kabupaten Bantul. Universitas Sanata Dharma.

Matondang, E. (2017). Finding Out the Potential of Nusa Tenggara Timur in Poverty Alleviation: The Effect of Local Government' s Policies. Jurnal Bina Praja, 9, (2), 231-242. https://doi.org/10.21787/ jbp.09.2017.231-242

Mustanir, A., \& Darmiah. (2016). Implementasi Kebijakan Dana Desa dan Partisipasi Masyarakat dalam Pembangunan di Desa Teteaji Kecamatan Tellu Limpoe Kabupaten Sidenreng Rappang. Jurnal Politik Profetik, 04, (2), 1-14.

Napitupulu, M.Y., Hakim, A. \& Noor, I. (2016). Penerapan Prinsip Good Governance Dan Pengaruhnya Terhadap Penyusunan Rencana Tata Ruang Wilayah ( RTRW ) Dalam Perencanaan Tata Ruang Daerah. Wacana, 19, (4), 196-205.

Nunkoo, R., Ribeiro, M. A., Sunnassee, V., \& Gursoy, D. (2018). Public trust in mega event planning institutions: The role of knowledge, transparency, and corruption. Tourism Management, 66, 155-166. https://doi.org/10.1016/j.tourman.2017.11.010

Nurlinah, H. \& Musdah, E. (2018). The Problem of Public Accountability in Village Governance in Rural Enrekang, Indonesia. Mimbar, 34, (2), 332-340.

OBE, H. B. (2017). Tenets of good corporate reporting.

Parapat, N., \& Yuliani, F. (2017). Penerapan Good Governance Dalam Penetapan Apbd. Jurnal Ilmu Administrasi Negara, 14,(3), 310-316.
Prasetyo, D., Suharno. \& Widarno, B. (2016). Kepatuhan Pemerintah Desa dalam Penggunaan Dana Desa Berdasarkan Peraturan Pemerintah RI No. 22 Tahun 2015. Jurnal Akuntansi Dan Sistem Teknologi Informasi, 12, (4), 417-427.

Rahman, F., Wiediartini, \& Sari, D.P. (2018). Penerapan Discriminant Analysis Untuk Mengetahui Faktor Yang Mempengaruhi Tingkat Kepuasan Pengguna Jasa Unit Layanan PPNS. SEMINAR MASTER 2018 PPNS, 1509, 51-54.

Richardo Juniaster Tampubolon. (2014). Pelaksanaan Prinsip Good Governance dalam Alokasi Dana Desa (ADD) di desa Teluk Bakau Kecamatan Gunung Kijang Kabupaten Bintan Tahun 2013. Tanjungpinang.

Rosielita, F., Sulindawati, N. L. G. E., \& Sinarwati, N. K. (2017). Implementasi Good Governance pada Pengelolaan Anggaran Pendapatan dan Belanja Desa (Studi Kasus pada Desa Telaga, Kecamatan Busungbiu, Kabupaten Buleleng). E-Journal S1 Ak Universitas Pendidikan Ganesha, 8, (2), 1-12.

Rustiarini, N. W. (2016). Good Governance dalam Pengelolaan Dana Desa. In Simposium Nasional Akuntansi (pp. 1-18).

Saha, S. K. (2014). Corruption and Good Governance: The Case of Bangladesh Corruption and Good Governance: The Case of Bangladesh. SUST Journal of Social Sciences, 22, (2), 45-52.

Salle, A. (2016). Makna transparansi dalam pengelolaan keuangan daerah. Jurnal Kajian Ekonomi Dan Keuangan Daerah, 1, (1), 1-19.

Sasundame, R. G., Tulusan, F., \& Kalangi, J. (2016). Penerapan Prinsip-Prinsip Good Governance dalam Pembuatan E-KTP di Dinas Kependudukan dan Catatan Sipil Kabupaten Minahasa Utara. Jurnal Administrasi Publik, 1, (043), 1-18.

Silalahi, U., \& Syafri, W. (2015). "Desentralisasi dan Demokrasi Pelayanan Publik" Menuju Pelayanan Pemerintah Daerah Lebih Transparan, Partisipatif, Responsif dan Akuntabel. Jatinangor: IPDN Press.

Subandi, A. (2017). Implementasi Kebijakan Dana Desa di Desa Neglasari Kecamatan Jasinga Kabupaten Bogor. Universitas Islam Negeri.

Sutiyo, \& Maharjan. (2017). Decentralization and Rural Development in Indonesia. Springer.

Ultafiah,W.(2017). Pengaruh Akuntabilitas, Transparansi, dan Partisipasi Terhadap Pengelolaan Dana Desa 
Untuk Mewujudkan Good Governance pada Desa di Kecamatan Merapi Barat Kabupaten Lahat. Universitas Muhammadiyah Palembang.

Utoyo, B. (2017). Analisis Kebijakan Prinsip Governance dan Aktor Melalui Analytical Hierarchy Process (AHP) dalam Perencanaan Kota. Spirit Publik, 12, (1), 45-56.

Widiyanti, A. (2017). Akuntabilitas dan Transparansi Pengelolaan Alokasi Dana Desa (Studi Pada Desa Sumberejo dan Desa Kandung di Kecamatan Winongan Kabupaten Pasuruan). Universitas Islam Negeri (UIN) Maulana Malik Ibrahim Malang. 51, (11), 1188-1197. https://doi. org/10.1111/j.1469-7610.2010.02280.x
Widiyanti, A. (2017). Implementation of Local Participation as Part of Good Governance Principles: Galengdowo Village Wonosalam Sub-District, Jombang. Jurnal Akuntansi Dan Keuangan, 19, (2), 59-66. https://doi.org/10.9744/ jak.19.2.59-66

Wijoyo, S., Salman, R., \& Abrianto, B. O. (2018). Making Model of Village Regulation based on Good Village Governance in Indonesia. Advance in Social Science, Education and Humanities Research (ASSEHR), 98, (Icpsuas 2017), 71-77.

Yuliansyah, \& Munandar. (2017). Kepatuhan Aparatur Desa dalam Penatausahaan Pengelolaan Keuangan Desa Berdasarkan Peraturan Menteri Dalam Negeri Nomor 113 di Wilayah Kecamatan Sambas Kabupaten Sambas. Jurnal Akuntansi, Ekonomi Dan Manajemen Bisnis, 5, (2), 181-192. 